\title{
'The teacher who helps children learn best': affect and authority in the traditional primary
}

\section{classroom}

\section{ABSTRACT}

This paper draws on the views of nearly 400 Year 5 pupils across nine classes in three schools. It explores how they perceived the role of affect in their classroom and how they conceived of their teachers' authority. The paper relates these views to the children's experiences of learning English in government primary schools in Alexandria, Egypt. The traditional role of the teacher in their schooling system was to transmit curriculum knowledge to pupils, whose feelings and social relationships were given little regard. By presenting pupils with sentences to complete, including one which started with 'The teacher who helps children learn best...', our research explored how this traditional approach influenced pupils in their English classroom. We also interviewed 38 pupils to explore their views further and we carried out Group Interviews with the pupils' teachers. We concluded that pupils were acutely aware of how their feelings and their relationship to the teacher influenced their capacity to learn cognitively. Many of them said that they did not respect those teachers who refused to exercise an ethic of care with them. In these cases, they did not see their teachers as authoritative and pupils' learning was impeded.

\section{Introduction: the pedagogic relationship}

Tone Saevi $(2015,350)$ recently suggested that, as a teacher:

Who I am and how I act is prior to any epistemological demands of knowledge, learning and outcomes.

This paper explores how children in a traditional primary classroom of government schools in Egypt, responded to 'who' the teacher in their class was and to how s/he acted as an authority figure in relation to pupils. Tone Saevi described the relationship between teacher and pupil as between human beings and embracing '... the necessary tension between authority and freedom expressed in the asymmetric relationship between adult and child' (344). In this current article, drawing on pupils' and their teachers' own voices, we explore this relationship and this tension as pupils describe learning English as a school subject. The article is inspired by the perceptions of a team of three researchers (one English, two Egyptian) that the pupils in these classes were not always satisfied with the affective 
relationship they had with some teachers, nor with how teachers exercised their authority with them. We aimed to explore whether this was the case and if so, where their dissatisfaction lay and how it influenced their learning. Our exploration made particular reference to pupils' perceptions of the pupils' feelings, especially those of being valued and feeling free; and of the teacher's authority.

\section{The teacher's authority}

Understanding the child-teacher authority relationship is central to understanding what goes on in classrooms (MacCloud et al 2002, 494).

At the base of the pedagogic relationship lies the fact that the adult teacher has the authority to ask the child to carry out certain acts and have these requests obeyed. The teacher's right or power to command her/his pupils, and be obeyed (i.e. authority), will be consented to by pupils to the extent that pupils accord with the teacher's legitimisation of that authority. When pupils see the teacher's power as legitimate, they are likely to give their consent to obey. When they do not see it as legitimate, the tension between teacher and pupils is likely to be greater.

In traditional classrooms, the source of teachers' legitimacy tends to lie in the teacher's 'traditional' or 'official/bureaucratic' authority, as prestigious members of society; or in their professional knowledge or expertise as 'epistemic' authority (Hoadley and Galant 2016, 1199). Max Weber himself (famous for his theories about authority) saw Arab culture, and the wielding of authority within it, as primarily traditional (Weber 1978, pp. 818-28, cited in Neal, Finlay and Tansay, 2005). In this case, the teacher's authority is assumed as 'the right to rule' by virtue of passed down rules and orders, regardless of the person's 'technical 
abilities or charisma properties' (Aguila and Vadera 2007, 440). The teacher earns a 'sense of status honor' (438) .

In the case of epistemic authority, the teacher's moral authority over pupils stems from their being the 'primary knower' (Nasaji \& Wells 2000). According to Bernstein (1971; 2000), within classrooms (such as the ones we observed) where the focus is on a well insulated (strongly classified) English-language curriculum, the teacher's knowledge of that curriculum is likely to be the most highly valued source of authority, which is how they reached their social position in the first place. Their authority thereby may be seen to rest on their membership of this elite 'club' of people who have access to this specialized knowledge, rather than resting on their capacity for distributing and helping reconstruct this knowledge among their students. In this scenario, the teacher may not believe s/he has to win respect by showing who $\mathrm{s} /$ he is or how she can relate in the classroom, because the specialist nature of the subject bestows authority on them by tradition. Added to that, the social position that this knowledge has bestowed on them legitimates their authority further, often in an unquestioned way. In other words, pedagogy and human relationships have been assigned a much lower value than subject expertise and the social position that accompanies this (Bernstein 1971; 2000). As Zembylas $(2007,355)$ pointed out, pedagogical strategies in recent years has come in some western countries to be seen as an integral part of teachers' pedagogical content knowledge (PCK); but even then, the emotional and affective aspects of that knowledge are still rarely acknowledged as integral.

Authority depends on pupils consenting to the teacher's claims to legitimacy as the superior. In the learning environment where children do not give their full consent, this teacher may resort to the use of coercion to impart their knowledge, leading to authoritarianism rather 
than authority being used to sustain order (Pace and Hemmings 2006). Freire described a possible confusion between authority which was based only on a teacher's traditional position as 'expert'; and authority based on a different kind of human knowledge that had the power to transform all people's experiences for the better. The former restricted relationships between teacher and pupils; while the latter opened these up. Freire described the danger if a teacher 'confuses the authority of knowledge with his or her own professional authority, which s/he sets in opposition to the freedom of ... students' (2000, 73). Carl Rogers (1951), preceding Freire, defined 'significant' learning, as opposed to superficial learning, as that which was more than an 'accumulation of facts' but rather was 'learning which makes a difference - in the individual's behaviour, in the course of action [s]he chooses in the future, in [her] his attitudes and in [her] his personality' (280). Rogers suggested that in significant learning the individual 'increasingly comes to feel that [the] locus of evaluation lies within [her-] himself' (119).

In other words, in the traditional classroom where curriculum knowledge is privileged over pedagogy or affective relationships, the teacher may assume an authority that is not perceived as legitimate by her/his students because it does not touch what they perceive to be 'significant' in their lives. It may be that these pupils do not in fact value subject expertise more highly than the teaching-learning process or affective relationships between human beings. In this case, the tension between authority and freedom becomes particularly problematic, with potentially destructive implications for learning. There are also some mid-way points between a position of authority and authoritarianism, such as the equivalent of the 'village elder' figure who could be more charismatic and encouraging like a mother or alternatively more coercive like a policeman (see Meighan and Harber 2007). 
In this article, we ask how the teacher's legitimation of authority affects her/his pedagogic relationship with the pupils in our sample, according to those pupils themselves. And we ask how this relationship influences pupils' feelings and ultimately their learning. We explore whether in fact the teacher does have their 'consent' to make them obey; or whether, alternatively, some teachers are imposing directives on them coercively, based on a traditional or official claim to authority rather than an authority founded in Freire's 'human knowledge that had the power to transform all people's experiences for the better' $(2000$, 73).

\section{Pupils' affective responses in the classroom}

One feature of strong classification and strong framing in the classroom, whereby subject knowledge is closely specified and the teacher has dominant power, is as follows:

The ... educational relationship tends to be hierarchical and ritualised and the pupils seen as ignorant, with little status and few rights.... knowledge is transmitted in a context where the teacher has maximal control or surveillance (Bernstein 1971, 57).

The Ministry of Education in Egypt has tight control over the content of what is taught in Egyptian classrooms and teachers have tight control over how it is taught, based on their access to the 'prescribed' body of knowledge. The pupils have practically no control over what is taught or how it is taught. Their views about the appropriateness of the learning process are therefore rarely valued and their feelings are likely to be seen as somewhat irrelevant to the process. This is a common scenario, not only in traditional classrooms, but in any classroom where the cognitive is prioritised over other potential aspects of learning. Andy Hargreaves $(2000,811)$ has suggested that this is particularly the case in western secondary schools, where teachers 'treat emotions as intrusions in the classroom'. This 
might apply also to the Egyptian primary classrooms we are discussing because of their secondary-style organisation from Year 1 upwards.

Hargreaves, however, suggests (812): 'Such emotions are not peripheral to people's lives; nor can they be compartmentalized away from action or from rational reflection within these lives'. The authors of Self Determination Theory (Ryan and Deci 2000) have also exemplified very rigorously, that cognitive competence does not necessarily lead pupils to progress further, unless the learner senses at the same time some freedom (autonomy) within the learning process and some relatedness to the teacher and other pupils (Niemiec and Ryan 2009). This suggests that a teacher's focus on subject content alone may be unproductive when this excludes taking into account pupils' own views and feelings and making a social connection with them. Noddings (2001), for example, has called for a return of the concept of 'caring' to the debate about teaching and learning. Where an 'ethic of care' dominates, pupils may have a stronger sense of being valued and feel more free to act according to their own 'perceived internal locus of control' (Niemiec and Ryan 2009). This will help them to progress with their cognitive focuses too. Michael Fielding and Peter Moss expressed this as follows:

Critical to pedagogical practice in radical education is re-envisioning relationships between adults and children within an ethic of care and adopting a dialogic approach of genuine openness and reciprocity. Ongoing, attentive dialogue between adults and children of all ages opens up understandings and opportunities for making meaning together $(2010,80)$.

Another body of research emphasises how negative feelings such as fear can interfere with cognitive processes of learning; and how an unfulfilled need to feel loved and wanted in the 
classroom can affect learning progress (Author; Jackson 2010; Moore 2013). This angle on learning environments tends to be minimised by policymakers because it is so hard to regulate and measure. However, research evidence suggests that cognitive competence is impeded when feelings of anxiety, fear or upset accompany the process; and where affective relationships are unsatisfactory. Where coercion has become the basis for teaching, as in many classrooms the world over, fear and other negative feelings are bound to be present too (Holt 1964) thereby threatening the very cognitive progress to which the teaching was directed.

In our Egyptian research, how children felt about their teachers' ethic of care, and opportunities for teachers and pupils making meaning together, surfaced as an important topic in our investigations. We therefore drew on our research data to explore in detail how pupils perceived that their feelings affected their learning of English, and in particular, how they seemed to connect feelings of being cared for and listened to, with the teacher's authority.

\section{Research design}

The research question for this study was: How do pupils experience the traditional classroom and what suggestions do they and their teachers express for making improvements to English language learning? The aim was to elicit and understand in depth how primary school pupils perceived their experiences of learning English in school. This paper emphasises the findings with reference to how they perceived their relationship with the teacher and how their feelings about this influenced their learning. Our methodology was interpretivist whereby we valued and explored the interpretations and meanings expressed 
in individual pupils' narratives. As a team of researchers, two Egyptian and one English, we used four data collection methods in two stages of research:

First stage: November 2015

1. Observation of 18 lessons, including English lessons, in three schools;

2. Written responses to sentence-starters of 393 pupils in these lessons.

Second stage: April 2016

3. Individual interviews with 38 pupils; and

4. Group Interviews with English teachers in each school.

We gained access in Alexandria, Egypt, to three government-funded primary schools of three different types: one Islamic school (School A); one 'official language' school (School B); and one 'mainstream' school (School C). Altogether we had the following participants:

Islamic school (School $\mathrm{A})=88$ pupils [27 BOYS; $61 \mathrm{GIRLS}$.

Official language school (School B) = 196 pupils [92 BOYS; 104 GIRLS].

Mainstream school (School C) = 110 pupils [61 BOYS; 49 GIRLS].

TOTAL = 394 PUPILS

Girls $=214$

Boys $=180$

However, one girl declined to complete the sentences so the total number of sentencestarter tasks completed was 393.

Observation 
In each school, we observed lessons of three classes of Year 5 pupils [aged 9-11 years]. To familiarize the pupils with ourselves, we firstly observed each research class during a lesson in a subject other than English. During these lessons we sat at the back of class and noted how pupils seemed to be responding to their teachers. We three researchers next observed and made field-notes about an English lesson for each class. After each observation, the three of us compared our observations and collated our notes. Our focus was on how the pupils seemed to be experiencing their English lessons in terms particularly of the relationship between the teacher and the pupils, for example, the occasions on which a teacher displayed or did not display care; whether or how a teacher seemed to share expertise with pupils, including opportunities pupils had for contributing to the lesson; and how pupils seemed to be feeling. We referred to our observation notes during our analysis of interview data and whilst reporting our findings, in particular, noting where our observations differed from perceptions expressed by pupils or teachers.

\section{Sentence-starters}

After each observed English lesson, the three of us worked together to present the sentence-starters to pupils. These were the first few words of a series of open-ended sentences that we invited pupils to complete. We took time to explain to pupils in detail what the purpose of the research was and what we would do with findings. We also answered their questions about the research. We explained that pupils' individual names would never be revealed in publications of findings (pseudonyms are therefore used for pupils and teachers, below). We emphasized in particular that their teachers would never know what any particular pupil had said. We gained the pupils' face-to-face consent before carrying out any activities with them. We also gained the teachers' and principal teachers' 
written consent. This research, both in its design and fieldwork, therefore adhered to the BSA ethical guidelines (2002).

In every classroom, as children completed the sentences, the two Egyptian researchers in our team went around the class giving support where necessary, but without putting any answers into pupils' minds. The seven sentence-starters explored pupils' views on the following respective areas: what pupils did in English classes that benefited them most and least; which kind of teacher helped them learn best; why they wanted to learn English; and how they felt about being included in this research. The responses were translated by our two Arabic-speaking team members. One sentence-starter was of particular interest to this article: 'The teacher who helps children learn best...' The responses to this prompt are used most extensively in this article because they relate most closely to the particular focus of this paper. However, pupils' responses to the other prompts were also included in the analysis and referred to as appropriate. A discussion of the pupils' responses to the whole range of sentence-starters can be found in Authors (2016).

\section{Individual interviews}

We selected 38 interviewees by reading through the sentence-completions and selecting those who appeared to be most engaged with the topic of research. We were careful to select both those who could write well and those who could not, as well as those who were outspoken and those who were less talkative. We asked each school to provide us with a quiet, private room in which to carry out the interviews where possible. All interviews were audio-recorded. Each child gave her/his specific permission to be interviewed and also to be audio-recorded in every case. One pupil declined to be interviewed. Interviews lasted between nine and 51 minutes. Seven girls were interviewed in each school. Six boys were 
also interviewed in two schools, five boys in the third. We asked the children about their aspirations, their experiences of learning English and their recommendations for change.

\section{Teacher Group Interviews}

We led Group Interviews with all primary English teachers in each school:

Islamic school (School A): 1 hour 53 minutes; 9 teachers

Official language school (School B): 1 hour 30 minutes; 6 teachers

Mainstream school (School C): 1 hour; 4 teachers.

The aim of the Group Interview was to hear the perspectives of the teachers about pupils' responses to the sentence-starters. In each Group Interview, we presented one pupil sentence-completion at a time and we invited the teachers to predict how the pupils had responded during the sentence-completion exercise. We then fed back to them the actual responses from the pupils across the three schools (having of course gained the pupils' consent to do so). Finally, we invited the teachers to reflect on and comment on all the pupil responses and make suggestions.

\section{Analysis}

As a team, we analysed responses using inductive approaches whereby we tried not to impose our own categories on the pupils' (or teachers') responses but rather attempted to let themes emerge. In our presentation of themes that emerged, we have aimed both to indicate dominant trends and to illustrate insightful special cases. We analysed all the data with a view to differences between girls and boys and across the three schools. While there were some noticeable differences between girls and boys, no significant differences were detected across the schools. 


\section{FINDINGS}

\section{Introduction}

The 393 pupils who completed sentence-starters told us that the teacher who helped children learn best was, in order of importance, the one who:

1. Helped pupils to learn and to understand: $N=99$ GIRLS; 78 BOYS

2. Treated them nicely: $\mathrm{N}=100 \mathrm{GIRLS} ; 74$ BOYS

3. Used helpful teaching strategies: $N=48$ GIRLS; 30 BOYS

4. Was calm: $\mathrm{N}=44 \mathrm{GIRLS} ; 21$ BOYS

5. Had a good rapport with pupils: N=41 GIRLS; 18 BOYS

6. Was conscientious: $\mathrm{N}=27 \mathrm{GIRLS} ; 22$ BOYS

7. Was humorous: $\mathrm{N}=13$ GIRLS; 18 BOYS

8. Made pupils actually use English in the classroom: N=12 GIRLS; 3 BOYS

9. Was good at English: N=8 GIRLS; 8 BOYS.

\section{Pupils valued an ethic of care}

This list suggests that cognitive learning outcomes in the form of mastery of the English syllabus were very important to these children. This was also clear from the fact that the pupils all seemed to pay attention in class and write down what they were told to write, even when sitting at the back of a very cramped class of 70 pupils or more. There was no doubt that many of them valued English as a school subject. However, it is significant that the most popular completions to the sentence-starter 'The teacher who helps children learn best...' focused particularly on affective factors linked to the affective relationship between the teacher and the pupils, rather than on cognitive learning outcomes. While the teacher's authority traditionally related to her/his subject expertise (and the social position this 
represented), even these pupils from very traditional classrooms were emphasising that such outcomes were also influenced by affective factors and relationships. Among their top ten priority traits of the teacher who helped children learn best, half related to feelings and affective relationships in the classroom: referring to the teacher who treated pupils kindly, had a good rapport with pupils, was calm, humorous and fair. Given that there were 213 girls and 180 boys in the sample, it can be seen that girls particularly emphasised the teacher's calmness [girls $n=44 \mathrm{v}$. boys $n=21$ ] and their good affective rapport with pupils [girls $n=41$ v. boys $n=18$ ]; while the boys stressed the importance of the teachers' humour [boys $n=18$ v. girls $n=13$ ].

It was striking and perhaps surprising that the pupils whom we interviewed and questioned were very aware of the hugely influential role that affective aspects of pupil learning had in the classroom. They could also see that their relationship with the teacher was one key trigger for their own feelings. Pupils noted the need, specifically, for the teacher who helps children learn best to be loved by pupils and to love them too, to be kind and friendly, fun and patient.

Perhaps as a summary conception of the ethic of care that pupils desired, several pupils told us that they would learn better if their teachers behaved like their parents or siblings. This did not seem to be in Meighan and Harber's (2007) sense of a senior person who enforces rules like a village elder, so much as someone who genuinely cares. The parent-child relationships they referred to tended to be informal and affectionate rather than formal and fear-based, despite vestiges of formality and hierarchy still being commonplace in Egyptian society outside the classroom as well as within (Wouters, 2009). For example, Murad in School B believed that the teacher who helps children learn best, would '... love us like 
his/her children; treat us generously'. Anas in School B considered the most effective teacher as the one with the parent-like attribute of having a genuine concern about pupils' futures: 'She would like us to do well when we grow up!' Carmen in School C described a real teacher who was helping her to learn well by showing that she cared about Carmen's feelings in a motherly way:

She asks us to always talk to her about anything that makes us upset. She says we are like her daughters and sons... I was once feeling unhappy and she came to me and asked me why I was sad and I told her and she helped me solve the problem. I think of her like a mum.

Some of these parental characteristics were recognised and appreciated by the pupils' teachers themselves, as the following extract from one of the teacher Group Interviews illustrated. The teachers' words resulted from our invitation to guess what the pupils had written about the teacher who helped them learn best:

Teacher1: First, I should love teaching.

Teacher2: We should be lovers of teaching.

Teacher3: Teachers should have good pronunciation. On top of that the pupil should like me.

Teacher1: [I should] be an amusing teacher.

Teacher2: I can tell you that so many of those who like English do so because they like their teachers. Maybe they are not good at teaching but the pupils like them and want to understand as much as they can from them. 
Teacher1: Yes. To underscore the words of Teacher2, what's more important than teaching itself is the teacher herself. The character of the teacher counts. I should build a good rapport with the pupils first so they can easily get the information from me. Second, we should be patient especially with such big numbers.

Teacher4: Yes. We should tell them that we love them and care about them. I do that.

Here Teacher 1 was exactly representing the words of Tone Saevi (2015) with which this article opened. This teacher was suggesting that the affective, relational aspects of the classroom had priority over the cognitive ones and that the latter were dependent on the former. This stance was, however, challenged by their further comments about the teacher's authority (see section below).

Some examples of pupils' awareness of the influential role of the teacher over their feelings are included in the following subsections, each of which is introduced by a representative pupil quotation.

'If I like the teacher, I will like the subject she teaches' As predicted by their teachers, pupils found it hard not to equate their affection for the English language with their relationship to their teacher. Tamara Bibby (2009) found a similar scenario in her ethnographic research in a UK primary classroom, whereby the pupils found it almost impossible to talk about their feelings towards a curriculum subject without reference to how much they liked its teacher. In the Egyptian sample, Carmen in School C, for example, told us:

If I like the teacher, I will like the subject she teaches. If I do not like the teacher, if they shout at us and hit us, I will not like the subject they teach. 
Hasnaa' in School A explained that it was important that the teacher loved the pupils too, not just the other way round:

If he loves the students and they love him, then they will follow what he says.

Yahia in School C summed the connection up, by commenting that caring teachers produced the best learning in a virtuous circle of good feeling:

If the teachers are nice to the students, they will make them like the English subject. If we like English, we will be able to answer well and get full marks. When we get full marks, the teacher will be proud of us and our fathers will be proud of us. When they are proud of us, they will make us feel good about ourselves and we will love English more!

One child illustrated how the teacher could demonstrate that s/he liked the pupils simply by saying hello when s/he arrived at the classroom. Mareena in School A explained, when she felt a 'strong rapport' with the teacher, 'he encourages me and makes me want to learn'. In contrast, Samia (School C) explained how bad relationships between teacher and pupils worked against learning her/his subject:

The teacher enters the classroom with a stick and she is shouting all the time. The students are rude to her and she gets rude in return. They say words and she shouts and says words in return... When the student stands up to read, he is liable to make mistakes and of course the teacher will hit him and shout and in this way the teacher makes the student upset. 
'When [the teacher] is kind-hearted and the class is enjoyable, this would make us understand everything'

Shereen in School B described the teacher who helps children learn best as follows:

He would laugh with us, have a sense of humour. He would play with us and laugh with us, not to make it only studying, studying.

Hasan in School B explained that he could understand English grammar rules better from a fun teacher:

Frankly speaking, the teacher who makes us act, have fun and play [helps children learn best]. To be honest, I sometimes understand the grammar rules from her.

Hani in the same school agreed:

When [the teacher] is kind-hearted and the class is enjoyable, this would make us understand everything.

Yahia in School C also emphasised the importance of having fun. He narrated:

We had a social studies teacher last year who used songs to teach us lessons and I really liked this way very much and I was able to learn better.

In contrast, Samia in School C again noted that the shouting teacher would make the student lose self-confidence and s/he would not want to study her/his subject again. However, Samia had also discovered a way to diminish the tension between the teacher and the class, which then allowed her to learn better:

The teacher enters the class and she is irritable. But then someone says something [amusing] and she laughs and things are ok and she starts to explain the lesson [in a good way]. We feel happy and can learn very well. 


\section{'She explains in a quiet and gradual manner. She does not get irritable easily'}

For the pupils, patience was often mentioned as a necessary characteristic of the teacher who helped them learn well, because with the patient teacher, they would not feel afraid to ask questions. They would feel free to ask the questions they needed to ask and to check their understanding with the teacher. They seemed to believe that fear was a restrictor of learning while patience tended to facilitate it. We asked Mazen in School C what an effective teacher does. He replied:

Whenever there is something we don't understand, she explains carefully.

However, it was primarily girls, in their sentence-completions, who explicitly told us that they wanted teachers to use a careful, patient approach [ $n=37$ girls v. $n=4$ boys]. Girls noted in particular, that when someone made a mistake, they found it more helpful if the teacher re-explained the topic rather than shouting at them. For example, Hana in School C told us her view of the most effective teacher:

She explains quietly, step by step. She does not shout. She explains in a quiet and gradual manner. She does not get irritable easily. She repeats explanations when someone has a problem understanding.

'I would like the English teacher not to be violent' While some pupils acknowledged the tough job teachers had, one of their most common requests to teachers was to stop shouting at and stop hitting pupils in order that learning improve. Pupils told us that when the teacher shouted at them or hit them or their peers it stopped them from learning because they felt 'distracted', 'confused', embarrassed', 'upset', 'angry', 'insulted' or 'afraid'. It made them hate their lessons. They seemed to find being shouted at or hit (sometimes with a stick) particularly offensive if it happened after a pupil made a mistake or 
asked a question. Anas in School A reported a divide between his father's assessment of appropriate teacher behaviour, and his own:

The teacher of Arabic, once I asked him a question and he reproached me saying, 'You are a donkey [stupid], you are dumb.' He should have answered the question; he would have nothing to lose if he had done... My dad came and said it was OK; but I didn't find it OK ... Learning stops.

Upset of any kind, especially fear of being beaten or shouted at, made learning more difficult as Yahia in School C stated categorically:

Hitting blocks our understanding and makes us unable to answer. Hitting makes us hate learning.

Meera in the same school explained how punishments made her dislike English:

I would like the English teacher not to be violent and not to hit anyone so that I am not afraid of her and I can learn English. When she hits me, I cannot like the English subject and I become afraid of it.

Mahmoud, also in School C, noted insightfully that fear or upset prevented the clear thinking necessary for effective learning:

If the teacher shouts at a student, she will be upset: she won't be willing to talk about the drawbacks of the lesson or learn from her mistakes.

Adel in School B was lucid in his portrayal of destructive feelings towards English resulting from other pupils being beaten in class:

Interviewer: What if the teacher shouts at or hits someone else in class, how does this affect you? 
Adel: This will make me stop liking English ... because my classmates are insulted ... I feel angry with the teacher.

In summary, our findings suggested that pupils found feelings to play a key role in their classroom learning. Outside the classroom, some social practices in Egypt displayed the formality and distance between people that we associate in the UK with the outdated 'stiff upper lip' of past ages, whereby emotions were repressed rather than expressed (Wouters, 2009). However, in our sample, pupils seemed aware of their feelings even when they had to keep them hidden. Pupils tended to equate fondness for the school subject with liking or loving the teacher so that if they had a poor relationship with their English teacher, their learning of English would suffer. Pupils seemed to learn best when they were enjoying themselves rather than when they were being shouted at or beaten. The threat of being shouted at or beaten increased their fear in the classroom which restricted their learning. They described needing patience from the teacher as $s /$ he explained lessons to them in a careful, gradual way.

\section{Pupils negotiated the legitimacy of the teacher's authority}

The section above illustrates children's perceptions of how affect was intertwined with learning and the important role in the learning process that was played by their affective relationship with the teacher. The next section demonstrates how the pupils seemed to conceptualise the authority relationship that they had with the teacher and where the children believed the teacher's power or right came from, which allowed her/him to have orders obeyed by the pupils. 
Pupils acknowledged the authority of the teacher who had pedagogic expertise

The 393 pupils who completed sentence-starters told us that the teacher who helped children learn best was the one who made them learn most. Very high on their list of 'the teacher who helps children learn best' was the teacher's skill in making them memorise and understand, which usually referred to the teacher's prowess in 'explaining' the lesson. We intuited that this portrayed some of their thoughts about the teacher's authority. This authority might entail the teacher's pedagogic skill and/or their ability to keep order in class so that pupils could listen and learn. The children's comments to us about teachers' pedagogical skills also tended to focus on her/his discipline. The teacher who helps children learn best was the one who did not rush onto the next topic before children had had a chance to understand the first topic; but who could also keep order. For many pupils, English lessons were difficult and they did not always understand what was going on. The pupils therefore seemed to find it particularly hard to respect the teacher who taught the lesson too fast or who let pupils misbehave. From these pupils' perspective, the teacher's authority seemed to lie in their capacity both for managing the class and explaining clearly.

Pupils believed that the teacher should be well educated and have personal charisma

Pupils also noted however that, to win their respect, the teacher needed to be very good at English and encourage pupils to use English. The teacher's subject specialism was important in terms of the authority they held in pupils' eyes. Merna from School C, among others, described how the teacher should be 'well educated', including knowing English very well. The idea of the well educated citizen that pupils also aspired to become was evident behind these references (see Peters, 1970; Martin, 1981). As Sameer in School A told us: 'They teach me so that I become hard working and well educated'. This was related to the idea 
among pupils that the teacher should in some sense be an upright human being who was conscientious and even 'humble' (Tokka, School B). The continuing huge class divide in Egyptian society may have supported the children's view that authority belonged to the educated teacher; however, 'humbleness' was a surprising addition to their conceptions (Wouters, 2009).

Related to being well educated was the idea of being charismatic. The teacher who helps children learn best for Hania in School B was 'the one who answers my questions seriously and wholeheartedly'. The children were here perhaps suggesting that they respected the authority of the teacher who had the knowledge and experience to teach English well; but who was also a good role model as a human being. Their image of the authoritative teacher did not stop at that teacher's possession only of subject or even pedagogical knowledge. In our data from interview and the children's writing, we thus detected some indications that the pupils were looking for a charismatic authority figure 'where authority is vested in the exemplary and charismatic personality of an individual person' (Hoadley and Galant, 2016). Adel in School B, for example, was explicit that he was looking for a high status figure in a teacher: 'Someone who has prestige and all pupils like him; in this way, he will gain their love'. A few pupils referred to the best teacher having a 'strong' character. However, as Reem in School B explained, this did not necessarily mean being harsh or authoritarian:

He would have a strong character. But he would make us love him because of the way he treats us not because he makes us afraid. We respect him because we love him not because we are afraid of him.

Janeen in the same school wrote how the passion of such a charismatic teacher might help them overcome difficulties: 
She makes us love her; this will make us do whatever she wants even if it's difficult for us.

This authoritative person would therefore be a person on whom pupils could model themselves (as opposed to the authoritarian person of whom the pupils were scared). In other words, the loveable teacher might also be the authoritative teacher in the sense of having personal charisma as the basis of her/his authority.

Some pupils consented to teachers exercising their authority through harsh means

Pupils had explained to us how an 'ethic of care' was essential for learning, but they did admit that a coercive approach was the most common approach to classroom management in all three schools (as in most schools the world over), whether this involved physical or psychological coercion. Some pupils seemed to give their blessing to this coercive way of managing the class, despite having praised the benefits of 'an ethic of care'. It seems that they consented to the teacher's harsh behaviour because they believed that the teacher's subject knowledge, teaching expertise and/or charisma gave them the right to use power in this way. In this sense, they were prioritising the teacher's authority, as they saw it, over their own thoughts, feelings, rights - and authority. This tendency can be linked to the tradition of authority within the Arab family (Al Suratty 2009). For example, Mazen in School C told us that for 'weak' students, 'We give them a chance and if they keep making mistakes we hit them'. In other words, when pupils did not follow the teacher's explanation, it was not the teacher's methods that were at fault, nor her/his subject knowledge, but the pupil's wilful 'deviancy' which only the teacher's punitive measures could counteract (Young 1971, 42). Acktem in School A was kind-hearted and told us that if he were a teacher he would 'forgive' students who made mistakes, but he was thereby 
again reinforcing the idea that mistakes were a deliberate act of defiance against authority rather than part of the process of learning. The image provided by Meighan and Harber (2007) of the teacher in a 'village elder' role is perhaps appropriate here: teachers' traditional authority, bestowed by traditionally high status, encouraged people to believe that they had the best interests of their inferiors at heart. The believed this even when there was no proof of this and even when pupils actually had their own proof of the opposite. Samreen in School B summed it up as follows:

I would learn best when the teacher is kind, encourages me to study, and explains well. She would be kind to the good students but wouldn't show any mercy to the bad ones.

Although many of the pupils were adamantly against either being shouted at (psychological punishment) or beaten (physical punishment), when we asked pupils for better pedagogic methods than shouting and hitting, other controlling (and humiliating) punishments were suggested. These included the common alternatives of psychological control, exchanges and incentives (Pace and Hemmings 2006). For example, Yulia in School A's suggestion was to put 'weak' pupils 'in an isolated part of the class all the school day so they would want to improve themselves to be like their good peers'.

In summary, some pupils saw a place in the classroom for some harsh punitive measures, and it seemed that these were permissible because of the teacher's authority they perceived, in terms of her/his superior knowledge, pedagogic experience, charisma or traditionally prestigious role as a teacher. What is still perplexing is a clash between their respect for this authority and their desire for an ethic of care. This is what Saevi (2015) referred to as '... the necessary tension between authority and freedom expressed in the 
asymmetric relationship between adult and child' (344). The teachers themselves

recognised this tension. They conveyed a desire to offer pupils more care than at present. However, they felt that communication was very difficult between teacher and pupils in the classrooms as they were presently, because of the large numbers and lack of space which seemed to push them into more traditionally authoritarian roles. This was why sometimes they had to shout at the pupils. One teacher explained:

Before I start the lesson, the class must be quiet. I suffer for 15 to 20 minutes to make them silent. They are naughty and violent. This is a problem. They must behave well first before proper teaching can happen in class... By the time they are silent, I am exhausted.

The legitimacy of authority based on teachers' traditionally prestigious role in society may still prove be the most powerful in the everyday hustle of the classroom, but it may also be the least secure at the present time. It is important to note that, in general, during the era of the research, teachers did not any longer have very high status in Egyptian society. Natural scientists seemed to be considered more prestigious than social scientists by many Egyptian people at the time of this study; and those working for private or foreign establishments were considered more prestigious than people working in Ministrydominated jobs, especially as teachers. Ministry-school teachers were not paid well, despite recent pay rises, and in the Egyptian culture, riches were a sign of prestige. It was noticeable that only three of the 38 pupils whom we interviewed aspired to become teachers when they grew up, even though at least ten of their parents were actually teachers. Pupils seemed to sense that their teachers were not highly qualified or properly trained and for that reason they held them in lower regard. These factors detracted from 
the idea that the teachers could rest on their traditional authority simply by nature of their position as a teacher. They suggested that traditional hierarchies were shifting.

Pupils called for more distributed authority, related to the ethic of care they desired

Although some pupils had sympathy with teachers' use of punitive measures in the classroom to assert their 'authority', others seemed to regard these as destructive, not only of the pupils' relationship with the teacher but also destructive of the teacher's authority itself. Two pupils even referred to teachers treating them like animals and servants, respectively, and requesting teachers to show more awareness of their humanity. For these pupils, the teacher's authority seemed to be actually legitimised by their genuine 'ethic of care' for them (Fielding and Moss 2014, 80): care about pupils' feelings, their views, their physical comfort, as well as their progress in English. These children hinted at the idea that a genuinely authoritative teacher would distribute her authority by allowing pupils to collaboratively construct it, by being regarded as genuine partners in it. They were going beyond the traditional emphasis on the teacher as subject expert with traditional authority. They saw that an ethic of care was inextricably linked to the authority of the teacher. Laura in School B confided that the teacher who helps children learn best and has their respect, would be "kind and friendly and like us to participate. He would understand our feelings and know how to treat us'. Deena in School C summed up this idea by proposing that pupils' respect for teachers demanded increased 'cooperation among teachers and students'. Merna (School C) went so far as to suggest that the teacher should not talk too much in class to allow pupils more opportunities to talk themselves. In other words, the authority of the teacher was based on a sense of mutual respect: 
He is not strict but challenges us to learn and focus. In my opinion, he should be nice and treat us with respect and this in turn will make us respect him and pay attention to him. These are the characteristics I need to have in my teacher (Mamdouh, School B).

\section{Discussion}

The children in this study were very focused on 'who' the teacher was, as well as on the teacher's expertise in teaching the subject of English. While they respected the teacher's authority as 'expert' in the subject of English and as legitimate because of the teacher's social position, as suggested by Bernstein's (1971) conception of the strongly classified classroom, they did not seem to feel that this expertise was enough to fully legitimise the teacher's authority. While they respected the teacher's expertise, they found it problematic for their own well-being that there was a tension between the teacher's expert authority and their own freedom; and as a consequence, their learning suffered too. They did not accept that they were 'ignorant, with little status and few rights' (ibid. 57). Their insightfulness about the process of classroom learning itself was evidence of their good grasp about how learning and teaching happened. And, as they pointed out themselves, they were neither slaves nor animals and should be credited with more authority than slaves and animals. In terms of learning, moreover, their insights led them to point out that in fact learning the subject matter does not progress so well when students feel undervalued. For the best learning situation, pupils needed to have their voices heard and responded to patiently by their teacher, who was a caring and conscientious person.

Our analysis of these comments was that for these pupils, sometimes the teacher's claims to authority needed to be based on the teacher's capacity to show care and concern in the 
classroom. To legitimise their authority, therefore, and have pupils' consent for the way learning and teaching were orchestrated, the teacher needed to have not only subject expertise, but also a caring and conscientious approach to learners. This way, pupils came to respect them, love the subject they taught and ultimately learn better. Sometimes, this care and concern could be demonstrated by the teacher using some harsh methods but on the whole, pupils advised the teacher to avoid these where possible in order to sustain their authority.

It is fascinating and perhaps sobering to note how children in this very traditional setting could place so much emphasis on the social context of the classroom, their feelings and their affective relationship with the teacher. This seems somewhat ironic, given the very low importance given to pupils' feelings in many teacher education courses the world over. The particularly striking aspect of their reflections is that they perceived these social factors - their feelings and the teacher's rapport with them - not as luxuries but as part and parcel of being able to learn English effectively as a subject. In Andy Hargreaves' words $(2000,811)$ cited earlier, they did not see affect as an intrusion but as a necessity for learning.

One aspect of the learning process that Niemiec and Ryan (2009) among other researchers considered equally important is pupils' sense of autonomy. Although the children in our study perceived that teachers' authority depended on their capacity to have a good rapport with children (ie relatedness), the pupils did not directly discuss autonomy in this context except in noting the need to be free from restrictive influences and to participate in the English class by 'making meaning together' with the teacher (Fielding and Moss, 2010, 80). None the less, the pupils' comments in the study suggested that they were ready and willing to be more autonomous and some pupils showed courage and innovation in proposing 
opposition to the status quo. These tendencies probably reflect the shifting power hierarchies in Egypt this century. While the rigid hierarchies of class and wealth continue to prevail there, some of the self-directedness assumed by pupils in UK classrooms seemed to be surfacing in the sample pupils' words. Such autonomy might be supported by what Benne (1970) named teachers' 'anthropogogical' authority.

According to Wouters' (2009) analysis of education and informalization in western Europe, respect for the authoritarian leader or teacher diminished in Europe in the 60s and 70s when social custom began to make it taboo to claim superiority over others. It seems that in Egypt the relaxing of formalities happened later, or is perhaps only occurring now. This may be due to the rise of social media, as well as mass migration, which have opened Egypt up in the past few years more than ever to outside influences. Our analysis is that this tendency towards informality is beginning to cause Egyptian pupils, parents, teachers and policymakers to question the feasibility of sustaining the formal, authoritarian system in schools, even when a formal, authoritarian system exists in other parts of society. As can be seen from many authoritarian classrooms in a democratic England, the classroom authority system may not reflect the acclaimed political system of the country. Other influences, for example from business, may be playing powerful, if concealed, roles (Giroux, 2005).

Pupils in this study supported Bibby's (2009) claim, that teaching is no longer just about being an expert in your subject: a teacher also now needs to be 'emotionally expert' and 'socially expert' (47]. However, the inclusion of emotional and social expertise in the concept of authority makes the teacher's job more difficult, albeit more valuable. Because emotional and social aspects of learning are unpredictable, or in Saevi's words, 'are potential but not fixed transactions' (Saevi, 2015, 247), the truly authoritative teacher must 
shoulder this uncertainty and face the fear of 'bewilderment' and 'loss of control' that Wouters (2009) referred to. While primary school teachers in the 60s and 70s in England may have been expert in these additional ways, this was not true in Egyptian government schools at the same time (Author1, 2001). In Egypt, these may therefore be less familiar aspects of the teaching profession, cultivated up till now primarily in their westernised international schools rather than the government schools. This is the challenge for the foreseeable future of Egypt's primary classrooms.

\section{REFERENCES}

Aguilera, Ruth V., and Abhijeet K. Vadera. 2008. "The Dark Side of Authority: Antecedents, Mechanisms, and Outcomes of Organizational Corruption." Journal of Business Ethics 77(4): 431-449.

Al Suratty, Y. 2009. Al Sultaweya fel Tarbeya al Arabia [in Arabic] (Authoritarianism in Arabic Education). Alam Al Maarefa: Kuwait.

Author1.

Author1.

Authors.

Benne, K. 1970. "Authority in Education". Harvard Educational Review 40(3): 385-410.

Bernstein, B. 1971. "On the Classification and Framing of Educational Knowledge". In Knowledge and Control, edited by Micheal Young, 47-69. London: Collier MacMillan.

Bernstein, B. 2000. Pedagogy, Symbolic Control and Identity: Theory, Research and Critique. Revised Edition. Oxford: Rowman \& Littlefield. 
Bibby, Tamara. 2009. "How do Children Understand Themselves as Learners? Towards a Learner-centred Understanding of Pedagogy." Pedagogy, Culture \& Society 17 (1): 41-55. Fielding, Michael, and Peter Moss. 2010. Radical Education and the Common School: $A$ Democratic Alternative. Abingdon: Routledge.

Giroux, Henry A. 2005. Against the New Authoritarianism: Politics after Abu Ghraib. Winnipeg: Arbeiter Ring Publishers.

Hargreaves, Andy. 2000. "Mixed Emotions: Teachers' Perceptions of their Interactions with Students." Teaching and Teacher Education 16.8 (2000): 811-826.

Hoadley, U. \& Jaamia Galant. 2016. “Specialization and School Organization: Investigating Pedagogic Culture". British Journal of Sociology of Education 37 (8): 1187-1210, DOI: $10.1080 / 01425692.2015 .1042149$

Holt, J. 1964. How Children Fail. Middlesex: Penguin.

Jackson, C. 2010. Fear in Education. Educational Review 62 (1): 39-52. DOI: $10.1080 / 00131910903469544$

Macleod, Gale, James MacAllister \& Anne Pirrie. 2012. "Towards a Broader Understanding of Authority in Student-teacher Relationships". Oxford Review of Education 38 (4): 493-508. DOI: $10.1080 / 03054985.2012 .716006$

Martin, Jane Roland. 1981. "The Ideal of the Educated Person." Educational Theory 31(2): 97-109.

Moore, A. 2013. Love and Fear in the Classroom: How 'Validating Affect' Might Help Us Understand Young Students and Improve their Experiences of School Life and Learning. In 
The Uses of Psychoanalysis in Working with Children's Emotional Lives edited by M.

O'Loughlin, 285-304. Maryland: Rowman and Littlefield.

Neal, Mark, Jim Finlay, and Richard Tansey. 2005. "My Father Knows the Minister" A

Comparative Study of Arab Women's Attitudes Towards Leadership Authority." Women in Management Review 20(7): 478-497.

Niemiec, Christopher P., and Richard M. Ryan. 2009. "Autonomy, Competence, and Relatedness in the Classroom: Applying Self-determination Theory to Educational Practice." Theory and research in Education 7 (2): 133-144.

Noddings, N. 2005. "Identifying and Responding to Needs in Education". Cambridge Journal of Education 35 (2): 147-159.

Pace, Judith L., and Annette Hemmings. 2007. "Understanding Authority in Classrooms: A Review of Theory, Ideology, and Research." Review of Educational Research 77 (1): 4-27.

Peters, R.S. 1970. Education and the Educated Man. Journal of Philosophy of Education 4 (1): $5-20$.

Rogers, Carl R. 2003 [1951]. Client-centered Therapy. London: Constable and Robinson. Ryan, R.M. and E. L. Deci. 2000. "Self-Determination Theory and the Facilitation of Intrinsic Motivation, Social Development, and Well-Being". American Psychologist 55 (1): 68-78.

Saevi, T. 2015. Learning and pedagogic relations. In Author.

Wouters, Cas. 2009. "Education and Informalization." Anales XII SIPC Procesos Civilizadores: 10-13.

Young, M. 1971. Knowledge and Control. London: Collier MacMillan. 
Zembylas, Michalinos. 2007. "Emotional ecology: The Intersection of Emotional Knowledge and Pedagogical Content Knowledge in Teaching." Teaching and Teacher Education 23(4): 355-367. 